\title{
Incidence and detection of sugarcane yellow leaf disease in the Philippines
}

\author{
Jay-Vee S. Mendoza ${ }^{1}$ (D) Marita S. Pinili $^{2} \cdot$ Fe M. Dela Cueva ${ }^{1}$ \\ Received: 3 July 2020 / Accepted: 15 November 2020 / Published online: 18 November 2020 \\ (C) Australasian Plant Pathology Society Inc. 2020
}

\begin{abstract}
A survey of sugarcane yellow leaf disease (SCYLD) was conducted in the Philippines. Sugarcane (Saccharum spp.) tissues showing the typical SCYLD symptoms were collected from eight provinces. Reverse Transcription Polymerase Chain Reaction (RT-PCR) identified ScYLV in samples from Batangas and Cebu, Philippines while there was no phytoplasma detected. ScYLV was able to transmit the disease using infected setts.
\end{abstract}

Keywords Sugarcane yellow leaf disease $\cdot$ Yellow leaf virus $\cdot$ Philippines $\cdot$ Detection

Sugarcane Yellow Leaf Disease (SCYLD) is known to be caused by Sugarcane yellow leaf virus (ScYLV) and sugarcane yellow leaf phytoplasma (SCYP) (Cronje et al. 1988; Schenck and Lehrer 2000). Although similar symptoms were reported to be caused by sugarcane white leaf phytoplasma in Thailand (Soufi et al. 2013). SCYLD is characterized by apparent yellowing of the leaf from the midrib that further leads to necrosis. Necrosis appears first on the older leaves. The lower surface of the midrib turns from green to bright yellow or pink or reddish. Dwarfism of the terminal internodes may also be observed (Lehrer and Komor 2008).

ScYLV is a Polerovirus belonging to the family Luteoviridae having monopartite, non-enveloped, isometric particles of 24 $29 \mathrm{~nm}$ diameter. The virus consists of single-stranded positive sense linear RNA genome (5900 nucleotides), icosahedral symmetry made of 180 coat protein units, with six open reading frames (ORFs 0,1,2,3,4, and 5) (Rott et al. 2008). So far, there are $9 \mathrm{ScYLV}$ genotypes known to occur in the world with great genetic diversity within species (Abu Ahmad et al. 2006a). The virus is efficiently transmitted by insect vectors, sugarcane aphids (Melanaphis sacchari) in a persistent, circulative manner (Rott

Jay-Vee S. Mendoza

jsmendoza5@up.edu.ph

1 Institute of Plant Breeding, College of Agriculture and Food Science, University of the Philippines Los Baños, College, 4031 Los Baños, Laguna, Philippines

2 National Crop Protection Center, College of Agriculture and Food Science, University of the Philippines Los Baños, College, 4031 Los Baños, Laguna, Philippines et al. 2008). Aside from M. sacchari, corn leaf aphid (Rhopalosiphum maidis) and rice root aphid (R. rufiabdominalis) are also known potential vectors of ScYLV. There is no reported mechanical transmission of ScYLV, however the virus can be transmitted by infected setts. Aside from sugarcane, ScYLV was successfully inoculated using viruliferous aphids on barley, sorghum, wheat, maize, sweet corn, and oats. A field planted with infected seeds is expected to suffer a yield loss of about $10-40 \%$ of total sugar yield (Rassaby et al. 2004).

In the Philippines, there had been cases of ScYLV detected from plants exhibiting SCYLD symptoms (Abu Ahmad et al. 2006b; Chatenet et al. 2001). Although little is known about the incidence and areas affected by the disease in the country. This study aims to confirm the presence of ScYLV and SCYP as a causal pathogen of ScYLD in the Philippines, determine the areas where the disease is present and find evidence of sett transmission of the virus.

Survey and collection was done at major sugarcane mill provinces; Batangas, Cavite, Negros Oriental, Negros Occidental, Iloilo, Cebu, Davao and Bukidnon in the Philippines (Sugar Regulatory Administration 2015). A total of 3 municipalities per province were randomly selected for sampling. Two fields were observed per municipality for a total of 6 fields per province. At least 100 representative plants regardless of symptoms were observed per field. Sampling was performed following a 'W-shaped' path covering the entirety of the fields (Lin et al. 1979). Any type of discoloration, necrosis and stunting symptoms were recorded and photo-documented. Leaf samples were collected and brought to the laboratory. A total of 100 samples exhibiting one or more typical SCYLD symptoms (yellowing of 
the midrib, stunting and necrosis) were selected per province for Reverse Transcription Polymerase Chain Reaction (RT-PCR) detection of ScYLV and nested PCR detection of phytoplasma. Stalk samples were collected for seed transmission study.

Representative cane stalks corresponding to the samples used in the RT-PCR assay were tested for sett transmission under greenhouse conditions. One-eyed setts measuring approximately $100 \mathrm{~g}$ were transplanted in plastic pots $(13 \mathrm{~cm}$ diameter by $10 \mathrm{~cm}$ depth) containing $1 \mathrm{~L}$ sterilized sandy loam garden soil medium. Uninfected VMC86-550 setts were also planted in the same conditions as negative control. Plants were maintained in screen cages, watered and fertilized (Complete 14-14-14). Chemical applications of Mancozeb, Thiotexam and Methomyl were used to prevent fungal and insect contamination. Discoloration, necrosis and qualitative plant growth were recorded monthly starting from germination until 12 months after transplanting. Leaf samples were collected at 4 months after transplanting and were subjected for virus detection using RT-PCR assay. (Arocha et al. 1999; Li et al. 2007)

RNA Extraction of 800 representative leaf samples were done using the TRIzol ${ }^{\mathrm{TM}}$ reagent (Invitrogen, USA) method for plant virus RNA (Chomczynski and Sacchi 1987; Xiang et al. 2001). Reverse transcription was done using Invitrogen Superscript III Reverse Transcriptase (Invitrogen, USA) following the manufacturer's instruction. Detection of ScYLV was done with RT-PCR using primers set YLS111 (forward: 5'-TCT CAC TTT CAC GGT TGA CG-3') and YLS462 (reverse; 5'-GTC TCC ATT CCC TTT GTA CAG C-3') coding for the coat protein region at approximately $350 \mathrm{bp}$ (Abu Ahmad et al. 2006a; Comstock et al. 1998). Leaves from uninfected VMC 86-550 sugarcane plants were used as negative check and a ScYLV positive sample from the sugarcane post-entry quarantine was used as positive check. DNA extraction of the same set of samples was done using a CTAB extraction based on the protocol of Honeycutt et al. (1992) A nested PCR assay using P1(forward: 5'-AAG AGT TTG ATC CTG GCT CAG GAT T-3') and P7 (reverse: 5'- CGT CCT TCA TCG GCT CTT-3') universal primers was done to detect phytoplasma (Valarmathi et al. 2013; Youssef et al. 2017). Leaves from uninfected VMC 86-550 sugarcane plants were used as negative check and a cassava witches broom (CWB) phytoplasma infected papaya sample from the Institute of Plant Breeding, University of the Philippines Los Banos (IPB-UPLB) was used as positive check. PCR products that yielded positive detection were sent for gene sequencing to Apical Scientific (Malaysia). NCBI BLAST search was then done using the resulting sequences.

RT-PCR assay of 800 representative samples using YLS111/462 primers detected ScYLV from two areas, Batangas and Cebu. Expected band size of $\sim 350$ bp was amplified from 2 out 100 samples from Batangas and 1 out of 100 from Cebu. Both positive samples from Batangas exhibited apparent yellowing of the midrib upon collection and came from the same field. The positive sample in Cebu exhibited apparent yellowing of the midrib with reddish discoloration on the underside of the leaves upon collection. While PCR detection using P1/P7 primers did not yield any positive results.

Plantlets grown from infected setts collected in Batangas and Cebu exhibited apparent yellowing in the midrib of the youngest leaves at 4 months after transplanting (Fig. 1). RTPCR detection using YLS 111/462 primers confirmed that the virus was transmitted in 1 out of 5 setts and 3 out of 5 setts for Batangas and Cebu stalk samples, respectively. Sequences from Batangas and Cebu were sent to the NCBI database with the GenBank accession numbers MT267538.1 and MT267539.1. Blast search results of these sequences exhibited $100 \%$ identity and $98-100 \%$ query cover with coat protein sequences of ScYLV from other sugarcane growing countries; China, Brazil, Mauritius and Peru.

Survey and detection proved that Sugarcane yellow leaf virus (ScYLV) is present in Batangas and Cebu at very low incidence $(\leq 2 \%)$. This affirms with the study of Chatenet et al. (2001) where they detected ScYLV from samples collected from sugarcane-growing countries including the Philippines. The incidence of ScYLV remained low even after two decades of its first report in the Philippines. This can be attributed to the slow spread of ScYLV at only 2-5 m each year on sugarcane fields via aphid vectors (Schenck and Lehrer 2000; Rassaby et al. 2004). Also disease screening and quarantine programs in the country could have controlled introduction or movement of infected materials (Dela Cueva and Samaco 2017; Paniza et al. 2020). It could also be noted that the survey did not include asymptomatic plants thus incidence could be higher as some ScYLD infected plants do not exhibit symptoms (Chatenet et al. 2001). Infected canes exhibited the ability to transmit the disease using propagative setts which have the potential for a higher rate, and long distance spread of the disease (Chinnaraja and Viswanathan 2015; Lehrer et al. 2007). Detection with $\mathrm{P} 1 / \mathrm{P} 7$ primers did not prove any

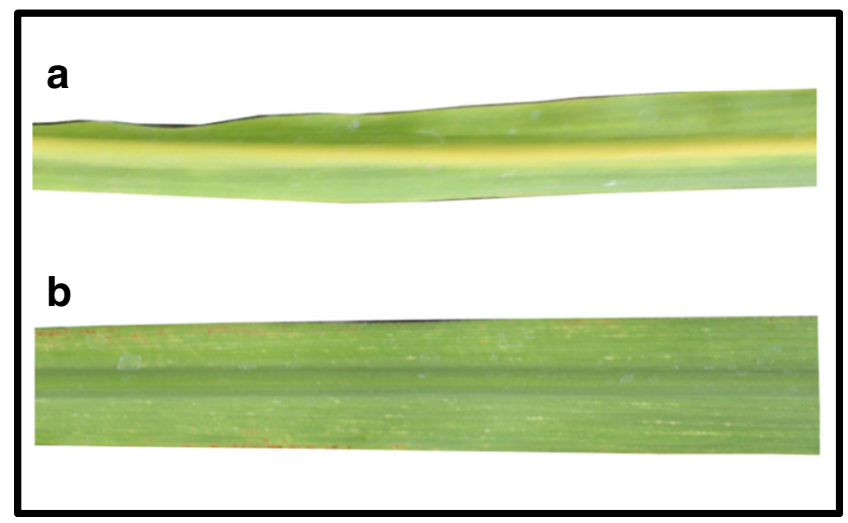

Fig. 1 Four months old sugarcane leaves a positive for Sugarcane yellow leaf virus (ScYLV) in comparison with an $\mathbf{b}$ uninfected plant 
presence of any phytoplasma in the samples exhibiting yellowing symptoms.

This study confirmed the presence of sugarcane yellow leaf virus (ScYLV) in the Philippines. At the time of collection, 2018, ScYLV is present in the country at a very low incidence $(\leq 2 \%)$. The spread of the disease appears to be very slow since the first report of this disease in 2001. The risk of an outbreak may be small however its ability to transmit disease through infected stalks is worth noticing for quarantine purposes. Therefore, immediate disease and virus management could be done to eradicate the disease while the incidence is low. Screening of planting materials for ScYLV can be done using YLS111/462 primers. Although there are a lot of primer sets for detecting ScYLV, this primer pair is able to amplify the CP gene of ScYLV with high reliability and for routine detection assay. Elimination and additional prevention can also be done by using tissue cultured planting materials (Parmessur and Saumtally 2002). Aside from virus-free planting materials, a more widespread survey can be done to cover more sampling sites across sugarcane-growing areas in the country. Asymptomatic plants may also be tested as some cases of plants infected with ScYLV does not show symptoms (Chatenet et al. 2001) Further studies investigating the phylogeny of the disease can also be explored for further understanding of the disease. A deeper understanding of known and other potential insect vectors and seed transmission can also be elucidated under controlled conditions. Finally, formulation of effective and integrated management strategies should be done to prevent the spread of the disease.

Acknowledgments We thank Eddie M. Bueta, Efren Ed C. Ledesma, Edwin E. Aquino and Jerymiah A. Cortejo for valuable technical support.

Funding This research was funded by UPLB-Sugar Regulatory Administration - Sugarcane Industry Development Act (SRA-SIDA) project. The Institute of Plant Breeding, College of Agriculture and Food Science, University of the Philippines Los Baños has provided inkind support.

\section{Compliance with ethical standards}

Conflict of interest The authors declare that they have no conflict of interests.

Ethical approval This article does not contain any studies with human participants or animals performed by any of the authors.

\section{References}

Abu Ahmad YA, Rassaby L, Royer M, Borg Z, Braithwaite KS, Mirkov TE, Irey MS, Perrier X, Smith GR, Rott P (2006a) Yellow leaf of sugarcane is caused by at least three different genotypes of sugarcane yellow leaf virus, one of which predominates on the island of Réunion. Arch Virol 151(7):1355-1371
Abu Ahmad Y, Royer M, Daugroi JH, Costet L, Lett JM, Victoria JI, Girard J, Rott P (2006b) Geographical distribution of four sugarcane yellow leaf virus genotypes. Plant Dis 90:1156-1160

Arocha Y, González L, Peralta EL, Jones P (1999) First report of virus and phytoplasma pathogens associated with yellow leaf syndrome of sugarcane in Cuba. Plant Dis 83(12):1177-1177

Chatenet M, Delage C, Ripolles M, Irey M, Lockhart BEL, Rott P (2001) Detection of Sugarcane yellow leaf virus in quarantine and production of virus-free sugarcane by apical meristem culture. Plant Dis 85: $1177-1180$

Chinnaraja C, Viswanathan R (2015) Quantification of sugarcane yellow leaf virus in sugarcane following transmission through aphid vector, Melanaphis sacchari. Virus Dis 26(4):237-242

Chomczynski P, Sacchi N (1987) Single-step method of RNA isolation by guanidium-thiocyanate-phenol-chloroform extraction. Anal Biochem 162:156-159

Comstock J, Irey M, Lockhart BE, Wang Z (1998) Incidence of yellow leaf syndrome in $\mathrm{CP}$ cultivars based on polymerase chain reaction and serological techniques. Sugar Cane 4:21-24

Cronje C, Tymon A, Jones P (1988) Bailey R (1988) association of a phytoplasma with a yellow leaf syndrome of sugarcane in Africa. Ann Appl Biol 133:177-186. https://doi.org/10.1111/j.1744-7348. 1998.tb05818.x

Dela Cueva F, Samaco M (2017) Disease screening and post-entry quarantine program for safe introduction of sugarcane varieties in the Philippines. J Int Soc SEAsian Agric Sci 23(1):33-43

Honeycutt RJ, Sobral BWS, Keim P, Irvine JE (1992) A rapid DNA extraction method for sugarcane and its relatives. Plant Mol Biol Report 10:66-72. https://doi.org/10.1007/BF02669266

Lehrer AT, Komor E (2008) Symptom expression of yellow leaf disease in sugarcane cultivars with different degrees of infection by sugarcane yellow leaf virus. Plant Pathol 57:178-189. https://doi.org/10. 1111/j.1365-3059.2007.01696.x

Lehrer A, Schenk S, Yan S, Komor E (2007) Movement of aphidtransmitted sugarcane yellow leaf virus (ScYLV) within and between sugarcane plants. Plant Pathol 56(4):711-717. https://doi. org/10.1111/j.1365-3059.2007.01557.x

Li L, Wang X, Zhou G (2007) Analyses of maize embryo invasion by sugarcane mosaic virus. Plant Sci 172(1):131-138

Lin CS, Poushinsky G, Mauer M (1979) An examination of five sampling methods under random and clustered disease distributions using simulation. Can J Plant Sci 59(1):121-130

Paniza H, Luzaran L, Dela Cueva F (2020) Sugarcane leaf scald: PHILSURIN's approach to minimize its threat. Academia. Retrieved September 23, 2020 from: http://www.academia.edu/ 30603770/SUGARCANE_LEAF_SCALD_PHILSURINS_ APPROACH_TO_MINIMIZE_ITS_THREAT

Parmessur, Y., Aljanabi, S., Saumtally, S. and Dookun-Saumtally, A. (2002), Sugarcane yellow leaf virus and sugarcane yellows phytoplasma: elimination by tissue culture. Plant Pathol 51:561566. https://doi.org/10.1046/j.1365-3059.2002.00747.x

Rassaby L, Girard JC, Lemaire O, Costet L, Irey MS, Kodja H, Lockhart B, Rott P (2004) Spread of sugarcane yellow leaf virus in sugarcane plants and fields on the island of Réunion. Plant Pathol 53(1):117125

Rott P, Mirkov TE, Schenck S, Girard J-C (2008) Recent advances in research on sugarcane yelow leaf virus, the causal agent of sugarcane yellow leaf. Sugar Cane Int 26(3):18-27

Schenck S, Lehrer AT (2000) Factors affecting the transmission and spread of sugarcane yellow leaf virus. Plant Dis 84(10):1085-1088

Soufi Z, Sakuanrungsirikul S, Wongwarat T et al (2013) Sugarcane yellow leaf symptomatic plants in Thailand are infected by white leaf phytoplasma, not by leaf yellows phytoplasma. Australas Plant Pathol 42:723-729. https://doi.org/10.1007/s13313-013-0238-7

Sugar Regulatory Administration (2015) Sugarcane Roadmap 2020: A Medium-Term Plan for the Philippine Sugarcane Industry; CY 
2014-2015 to 2019-2020 Version. Retreived March 3, 2020 from: http://www.sra.gov.ph/wp-content/uploads/2016/03/ SUGARCANE-ROADMAP-2020_final_03022016.pdf

Valarmathi P, Rabindran R, Velazhahan R, Suresh S, Robin S (2013) First report of rice orange leaf disease phytoplasma (16 SrI) in rice (Oryza sativa) in India. Aust Plant Dis Notes 8(1):141-143
Xiang X, Qiu D, Hegele RD, Tan WC (2001) Comparison of different methods of total RNA extraction for viral detection in sputum. J Virol Methods 94(1-2):129-135

Youssef SA, Sayed Y, Hassan OS, Safwat G, Shalaby AA (2017) Universal and specific 16S-23Sr RNA PCR primers for identification of Phytoplasma associated with sesame in Egypt. Int J Adv Res Biol Sci 4:191-200 